University of Nebraska - Lincoln

DigitalCommons@University of Nebraska - Lincoln

Agronomy \& Horticulture -- Faculty Publications

Agronomy and Horticulture Department

2002

\title{
Comparative Ecophysiology of Grain Sorghum and Abutilon theophrasti in Monoculture and in Mixture
}

\author{
Samba Traoré \\ University of Nebraska-Lincoln \\ John L. Lindquist \\ University of Nebraska-Lincoln, jlindquist1@unl.edu \\ Stephen Mason \\ University of Nebraska-Lincoln, smason1@unl.edu \\ Alex Martin \\ University of Nebraska-Lincoln, amartin2@unl.edu \\ D. A. Mortensen \\ University of Nebraska-Lincoln
}

Follow this and additional works at: https://digitalcommons.unl.edu/agronomyfacpub

Part of the Plant Sciences Commons

Traoré, Samba; Lindquist, John L.; Mason, Stephen; Martin, Alex; and Mortensen, D. A., "Comparative Ecophysiology of Grain Sorghum and Abutilon theophrasti in Monoculture and in Mixture" (2002). Agronomy \& Horticulture -- Faculty Publications. 508.

https://digitalcommons.unl.edu/agronomyfacpub/508

This Article is brought to you for free and open access by the Agronomy and Horticulture Department at DigitalCommons@University of Nebraska - Lincoln. It has been accepted for inclusion in Agronomy \& Horticulture -Faculty Publications by an authorized administrator of DigitalCommons@University of Nebraska - Lincoln. 
Published in Weed Research 42:1 (2002), pp. 65-75; doi: 10.1046/j.1365-3180.2002.00263.x

Copyright 2002 European Weed Research Society. Used by permission.

Published online February 25, 2002

\title{
Comparative Ecophysiology of Grain Sorghum and Abutilon theophrasti in Monoculture and in Mixture
}

\author{
S. Traoré, J. L. Lindquist, S. C. Mason, A. R. Martin, and D. A. Mortensen \\ Department of Agronomy, University of Nebraska-Lincoln, Lincoln, NE 68583-0817, USA \\ Corresponding author - J. L. Lindquist, Department of Agronomy, University of Nebraska-Lincoln, \\ Lincoln, NE 68583-0817, USA; tel 402 472-2771; fax 402 472-3654; e-mail jlindquist1@unl.edu
}

\begin{abstract}
Selection of crop genotypes that are more competitive with weeds for light interception may improve crop yield stability in the presence of weeds. The effects of interference on ecophysiological characteristics of Abutilon theophrasti Medic. and three morphologically diverse grain sorghum hybrids was evaluated to determine the relative tolerance and suppressive ability of the three hybrids and specific traits that may contribute to those differences. A tall hybrid was more tolerant to $A$. theophrasti interference than two medium stature hybrids. Early leaf area growth of two medium-stature sorghum hybrids was reduced by $A$. theophrasti interference, whereas early growth of a tall hybrid was unaffected. The height of $A$. theophrasti was greater than two moderate-stature hybrids but lower than the tall hybrid. Greatest leaf area density $\left(\mathrm{L}_{\mathrm{D}}\right)$ of the tall sorghum hybrid was above that of A. theophrasti, whereas greatest $\mathrm{L}_{\mathrm{D}}$ of medium-stature hybrids was below that of the weed. In monoculture, the partitioning of new biomass to various plant organs was similar among sorghum hybrids, whereas the tall sorghum hybrid partitioned less biomass to leaves and more to stems than medium hybrids in mixture. The results indicate that the three hybrids differ in their susceptibility to A. theophrasti competition. Crop traits that may contribute to greater crop competitiveness include greater maximum height and its growth rate and greater height of maximum leaf area distribution.
\end{abstract}

Keywords: Abutilon theophrasti, competition, velvetleaf, growth analysis, leaf area distribution

\section{Introduction}

Sorghum [Sorghum bicolor (L.) Moench] is the fifth most important cereal crop worldwide and a major staple food of people in the semi-arid tropics (ICRISAT, 1990). Sorghum yield loss resulting from grassy weeds and Striga spp. could reach $80-100 \%$ depending on rainfall and soil fertility (Lagoke et al., 1991). Chandler (1981) estimated that weed competition costs sorghum producers almost $\$ 250$ million per year in yield reductions in the USA. Abutilon theophrasti Medic. (velvetleaf) is an important weed throughout the region in which maize (Zea mays L.) and soyabean (Glycine max [L.] Merr.) are grown in the USA, and its geographical range is still expanding (Spencer, 1984). Roeth et al. (1983) reported that $A$. theophrasti has increased dramatically in
Nebraska and is now considered one of the most troublesome weeds in sorghum.

Concerns over herbicide resistance and non-target effects of herbicide use in many developed countries, as well as their low accessibility in developing countries, have resulted in a need to develop integrated approaches to weed management in many agricultural systems. Improved cultivar competitiveness and tolerance to weeds were suggested as methods of reducing the negative effects of weeds on crop yield (Jordan, 1993). Under adequate soil nitrogen and water, competition for light is the primary cause of yield loss from weeds (Munger et al., 1987). Competition for light is an instantaneous process that depends on the relative share of available light absorbed by a species in a mixed canopy and the efficiency of energy use in dry matter pro- 
duction (Lawlor, 1995). Light absorption in mixed canopies is determined by the leaf area index (LAI) of the species, plant height, vertical leaf area distribution and leaf angle distribution (Lindquist \& Mortensen, 1999). Lindquist \& Mortensen (1998) showed that morphologically different maize hybrids differed in their tolerance to and ability to suppress A. theophrasti seed production. Weed interference studies in sorghum are limited in number, and little is known about the interference between $A$. theophrasti and sorghum.

The first objective of this research was to compare the tolerance and relative suppressive ability of three sorghum hybrids grown in mixture with $A$. theophrasti. The second objective was to compare sorghum and $A$. theophrasti growth and canopy characteristics to evaluate which may contribute to differences in tolerance and weed suppressive ability.

\section{Materials and methods}

Experiments were conducted during two growing seasons in 1996 and 1997 at the University of Nebraska Agronomy Farm at Havelock, Nebraska $\left(40^{\circ}\right.$ $50^{\prime} \mathrm{N}, 96^{\circ} 36^{\prime} \mathrm{W}$; $347 \mathrm{~m}$ a.s.l.), and at the Agricultural Research and Development Center near Mead, Nebraska $\left(41^{\circ} 14^{\prime} \mathrm{N}, 96^{\circ} 29^{\prime} \mathrm{W} ; 370 \mathrm{~m}\right.$ a.s.l). Soils at both sites are a Sharpsburg silty clay loam (fine, smectitic, mesic, Typic Argiudoll) with $3.2 \%$ and $2.6 \%$ soil organic matter respectively. Treatments consisted of a factorial combination of three grain sorghum hybrids and three weed infestation levels arranged in a splitplot treatment design with four replicates. Sorghum hybrids were treated as whole plots and weed infestation levels as subplots. Sorghum hybrids were selected on the basis of their variation in height, leaf area and leaf display (Dekalb FS2 tall $\geq 1.8 \mathrm{~m}$; Dekalb DK54 and Dekalb X260 medium tall $\leq 1.5 \mathrm{~m}$; Dekalb; Monsanto, St Louis, MO, USA). Similarity in time to maturity among sorghum hybrids was intentionally selected to avoid any confounding between the effect of hybrid morphology and differential crop growth stage. Weed infestation treatments included monoculture crop (completely weed-free), low weed infestation level (A. theophrasti emerged after herbicide application 2 weeks after crop emergence) and high weed infestation level (A. theophrasti present during the entire growth cycle of sorghum). An experimental unit was a six row (0.76 m apart) by $15 \mathrm{~m}$ plot. Maize and sorghum were grown 1 year before the establishment of these experiments at Mead and Havelock respectively. Fields were disked in spring for seedbed preparation, and phosphorus and nitrogen fertilizers were applied at $20 \mathrm{~kg} \mathrm{P} \mathrm{ha}{ }^{-1}$ and $36 \mathrm{~kg} \mathrm{~N} \mathrm{ha}^{-1}$. Sorghum was seeded at 180,000 seeds ha ${ }^{-1}$ with a John Deere max-emerge planter (Deere \& Co., Moline, IL, USA) containing
Kinze D8524 (Williamsburg, IA, USA) plates to allow precise seed spacing. Abutilon theophrasti seeds were broadcast at $25 \mathrm{~kg} \mathrm{ha}^{-1}$ over the entire area at planting using a PTO-driven fertilizer spreader at both locations in 1996 and at Havelock in 1997. A hand spreader was used at Mead in 1997. Weed seeds were presoaked in a $70{ }^{\circ} \mathrm{C}$ hot water bath for $4-5 \mathrm{~min}$, then dried at room temperature to increase germination rate (Khedir \& Roeth, 1981). Planting dates were June 6 and 7, 1996, and June 2 and 4, 1997, for Havelock and Mead respectively. Timing of weed removal reflected common practice in the area. Propachlor (Ramrod, $480 \mathrm{~g}$ a.i. $\mathrm{L}^{-1}$; Monsanto) was applied at $6.5 \mathrm{~kg}$ a.i. $\mathrm{ha}^{-1}$ at planting to control common grasses. Bentazon (Basagran, $480 \mathrm{~g}$ a. i. $\mathrm{L}^{-1}$; BASF, Research Triangle Park, NC, USA) was applied at $0.84 \mathrm{~kg}$ a.i. $\mathrm{ha}^{-1}$ with $28 \%$ urea ammonium nitrate (UAN) solution to control $A$. theophrasti at the three-leaf stage in weed-free and low weed infestation level treatments. Abutilon theophrasti plants emerging after treatment were removed by hand in the weedfree treatment, but allowed to compete with the crop in the low weed infestation treatment. No post-emergence herbicide was applied to the high infestation level treatments, but weeds other than $A$. theophrasti were removed by hand as needed.

Two plants of both sorghum and A. theophrasti were destructively harvested weekly in each plot to assess dry matter accumulation beginning 2 weeks after emergence and ending at physiological maturity. One plant was randomly identified in each of rows 2 and 5 of each experimental unit, ensuring that at least $1 \mathrm{~m}$ separated it from a previously harvested plant. Plant height was measured before clipping plants at the soil surface. Height was measured to the extended tip of the tallest leaf before sorghum anthesis and to the top of the panicle after anthesis. Abutilon theophrasti height was measured to the highest point on the main stem. Harvested plants were separated into green leaves, stems and reproductive tissue. Green leaves were separated by cutting the lamina at the collar for sorghum or at the attachment of the petiole to the lamina for $A$. theophrasti. The panicle was separated from the stem at the last node. Leaf area was measured with an area meter (LI3100, LiCor, Lincoln, NE, USA) and oven dried at $60^{\circ} \mathrm{C}$ to constant mass. At early boot stage, 10 plants were randomly selected from each treatment in two replicates and clipped at the soil surface. Plants were separated as described above into different plant organs. The leaf area was determined and oven dried to determine the specific leaf area (SLA; $\mathrm{m}^{2} \mathrm{~g}^{-1}$ ), which was used to calculate leaf area from leaf biomass at subsequent harvests. To determine the extinction coefficient for diffuse radiation, photosynthetic photon flux density (PPFD) was measured at sorghum anthesis under uniform overcast sky conditions in monoculture treatments at both locations in 1997. Attenuation of only 
diffuse radiation was measured because extinction coefficients for the direct components of radiation can be derived from that for diffuse radiation (Spitters, 1986). A line quantum sensor (LI-191SA; LiCor) and a point sensor (LI-190SA; LiCor) were used simultaneously to measure incident PPFD at $0.2 \mathrm{~m}$ intervals within and above the canopy respectively. Two plants were harvested where PPFD measurements were taken and separated into leaves, stems and reproductive organs using a stratified clip at 0.2-m height intervals. Leaf area was determined for each height interval, and tissues were dried to constant weight.

\section{Data analyses}

Phenological development was quantified using a dimensionless scale where 0 represents emergence, 1 is sorghum anthesis or $A$. theophrasti flower initiation, and 2 is sorghum physiological maturity or complete loss of $A$. theophrasti leaves. Development stage is calculated from thermal units (TU) accumulated after plant emergence using a base temperature of $10^{\circ} \mathrm{C}$ for $A$. theophrasti (Lindquist et al., 1998) and $15^{\circ} \mathrm{C}$ for sorghum (Eastin, 1972). Estimates of canopy characteristics were obtained for each experimental unit using methods outlined by Lindquist et al. (1998) and Lindquist \& Mortensen (1999). Characteristics measured included: apparent leaf area index at emergence $\left[\ln \left(\mathrm{LAI}_{\mathrm{o}}\right)\right]$ and early leaf area growth rate (RGRL), which were obtained from a regression of $\ln (\mathrm{LAI})$ on thermal time from emergence until LAI approaches 1.0; thermal time from emergence to $50 \%$ maximum height $\left(\mathrm{H}_{\mathrm{a}} / \mathrm{H}_{\mathrm{b}}\right)$ and maximum height $\left(\mathrm{H}_{\mathrm{m}}\right)$, obtained by fitting measured height on thermal time (TU) using the logistic function (height $=\mathrm{H}_{\mathrm{m}} /\left[1+\exp \left(\mathrm{H}_{\mathrm{a}}-\mathrm{H}_{\mathrm{b}} \mathrm{TU}\right)\right]$; leaf area distribution, quantified using $\mathrm{LAI}_{\mathrm{r}}=1-\exp \{-$ $\left.\left[\left(\left(1-\mathrm{HT}_{\mathrm{r}}\right) / \mathrm{LD}_{\mathrm{a}}\right) \mathrm{LD}_{\mathrm{b}}\right]\right\}$, where $\mathrm{LAI}_{\mathrm{r}}$ is relative LAI at relative height $\mathrm{HT}_{\mathrm{r}}, \mathrm{LD}_{\mathrm{a}}$ is relative height of maximum leaf area density (from the top of the canopy), and $\mathrm{LD}_{\mathrm{b}}$ defines the slope of the leaf area density relationship; specific leaf area (SLA); biomass partitioning coefficients $\left(\mathrm{P}_{\mathrm{C}}=\Delta \mathrm{W}_{\mathrm{C}} / \Delta \mathrm{W}_{\mathrm{T}}\right.$, where $\Delta \mathrm{W}_{\mathrm{C}}$ is the change in biomass of organ group $c$, and $\Delta W_{T}$ is the change in total above-ground biomass). Extinction coefficient estimates were obtained for each experimental unit of the monoculture treatments in 1997. Least squares linear and non-linear regression analyses were used to obtain estimates of canopy characteristics for each experimental unit. After testing parameter estimates for homogeneity of variance, differences among hybrids were tested using analysis of variance (SAS, 1996). Simple effects (i.e. hybrid $\times$ weed infestation at a given level of weed infestation) were evaluated when hybrid $\times$ weed infestation level interaction was present. In the absence of a hybrid $\times$ weed infestation level interaction, single degree of freedom contrasts were used to compare esti- mates among sorghum hybrids or among weed infestation levels. Data were not combined because weed infestation levels differed among sites and years.

\section{Results and discussion}

\section{Weather, phenology and plant population}

Rainfall was greater and more evenly distributed in 1996 than in 1997 at Havelock and was above the longterm average during the maximum growth stage in 1996. Rainfall in both years at Mead was similar to that for Havelock in 1996. Cooler minimum and maximum temperatures were recorded in 1996 than in 1997 at both locations (Traoré, 1999).

Monoculture-grown DK54 reached physiological maturity 5 days later than the other two hybrids at Havelock in 1996. Anthesis and physiological maturity of medium-stature hybrids were delayed 5-9 days when grown in mixture with $A$. theophrasti (Traoré, 1999). Abutilon theophrasti flower initiation did not differ in mixture compared with monoculture, probably because it is more sensitive to photoperiod than to interspecific competition.

Sorghum population averaged 14 and 15 plants $\mathrm{m}^{-2}$ at Havelock and Mead, respectively, in 1996, and 15 plants $\mathrm{m}^{-2}$ at both locations in 1997. Weed monoculture densities averaged 27.7 and 12.8 plants $\mathrm{m}^{-2}$ in 1996 and 1997 at Havelock, and 29.2 and 26.6 plants $\mathrm{m}^{-2}$ at Mead. Insufficient $A$. theophrasti plants emerged after herbicide application in the low $A$. theophrasti infestation treatment to allow measurements to be taken on the weed. However, the effects of these few weeds on sorghum were evaluated. The high $A$. theophrasti infestation treatments averaged 32.6 plants $\mathrm{m}^{-2}$ in mixture with sorghum hybrids at Havelock in 1996 and only 2.6 plants $\mathrm{m}^{-2}$ in 1997, mainly because of insufficient moisture during early growth. At Mead, A. theophrasti in mixture averaged 28.2 and 20.5 plants $\mathrm{m}^{-2}$ in 1996 and 1997 respectively. Weed populations did not differ in mixture except at Mead in 1996, where $A$. theophrasti in mixture with the tall sorghum was greater (35 plants $\mathrm{m}^{-2}$ ) than in mixture with the medium hybrids (25 plants $\mathrm{m}^{-2}$ ).

\section{Sorghum tolerance and $A$. theophrasti suppressive ability}

Tolerance of the three sorghum hybrids to $A$. theophrasti interference was evaluated by comparing the per plant biomass $(\mathrm{w})$ of sorghum in mixture relative to its biomass in monoculture $\left(\mathrm{w}_{\text {mix }} / \mathrm{w}_{\text {mono }}\right)$ at the sample taken near physiological maturity. This allows for a 
clear comparison among hybrids, even though their biomass in monoculture may have differed. Relative yield of sorghum in the low infestation treatments did not differ from that in monoculture treatments, so only high infestation treatments will be discussed. Compared with the two medium hybrids, the tall hybrid had greater biomass in mixture relative to monoculture at both locations in 1996 (Table 1). Although the same trend was true in 1997,

Table 1. Mean sorghum relative per plant biomass $\left(w_{\text {mix }} /\right.$ $\mathrm{w}_{\text {mono }}$ ) near physiological maturity and $A$. theophrasti per plant biomass in mixture as influenced by sorghum hybrid.

\begin{tabular}{cllcc}
\hline Year & Site & Hybrid & $\begin{array}{c}\text { Sorghum } \\
\text { relative } \\
\text { yield }\end{array}$ & $\begin{array}{c}\text { A. theophrasti } \\
\text { biomass } \\
\text { in mixture } \\
\left.\text { (g plant }^{-1}\right)\end{array}$ \\
\hline 1996 & Havelock & FS2 & 0.930 & 28.92 \\
& & DK54 & 0.459 & 28.44 \\
1996 & Mead & X260 & 0.513 & 24.17 \\
& & SE & 0.0626 & 5.900 \\
1997 & FS2 & 0.946 & 18.43 \\
& & DK54 & 0.728 & 26.40 \\
& & X260 & 0.794 & 23.37 \\
& & SE & 0.0750 & 1.825 \\
& & FS2 & 0.841 & 20.06 \\
& & DK54 & 0.770 & 33.64 \\
& & X260 & 0.791 & 21.69 \\
& Mead & SE & 0.1186 & 5.543 \\
& & FS2 & 0.924 & 3.93 \\
& & DK54 & 0.807 & 6.00 \\
& & X260 & 0.846 & 2.90 \\
& & SE & 0.0572 & 1.184 \\
& & & & \\
\hline
\end{tabular}

differences were not statistically different. These results indicate that the tall hybrid is more tolerant of $A$. theophrasti interference than the two medium hybrids.

The relative ability of the three sorghum hybrids to suppress $A$. theophrasti growth was evaluated by comparing $A$. theophrasti per plant biomass at the final sampling time of the season. Weed biomass was lower in the presence of the tall hybrid compared with the two medium hybrids at Mead in 1996 (Table 1), indicating that the tall hybrid suppressed its growth more than the medium hybrids did. At Mead in 1997, A. theophrasti biomass per plant was greatest in the presence of DK54, indicating that this hybrid was less suppressive than either X260 or FS2. No differences in A. theophrasti per plant biomass were observed at Havelock.

\section{Canopy characteristics}

Early leaf area growth rate

A hybrid $\times A$. theophrasti infestation level interaction was observed at Havelock in 1996 and at Mead in 1997 for early leaf area growth rate (RGRL, Table 2). In monoculture treatments, the tall sorghum hybrid (FS2) generally had smaller RGRL than the medium hybrids, whereas RGRL did not differ among sorghum hybrids in mixture (Tables 3 and 4). Thus, early leaf area growth of the two medium hybrids was reduced by $A$. theophrasti interference, whereas early growth of the tall hybrid was not affected. Apparent leaf area index at emergence $\left[\ln \left(\mathrm{LAI}_{\mathrm{o}}\right)\right]$ was smaller for DK54 than for the other hybrids across all weed treatments at Mead (Tables 3 and 4). Although DK54 had an apparent disadvantage at emergence, its growth rate was not reduced by $A$. theophrasti interference.

Table 2. Analysis of variance showing probabilities (P-values) of the main effects of sorghum hybrid $(\mathrm{H})$, weed pressure $(\mathrm{W})$ and their interactions on sorghum mean estimated regression coefficients for apparent leaf area at emergence [In( $\left.\left.\mathrm{LAl}_{\mathrm{o}}\right)\right]$, early leaf area growth rate $\left[R G R L\left(d^{\circ} \mathrm{C}\right)^{-1}\right]$, thermal time to $50 \%$ maximum height $\left(\mathrm{H}_{a} / \mathrm{H}_{b}, \mathrm{~d}^{\circ} \mathrm{C}\right)$, maximum height $\left(\mathrm{H}_{\mathrm{m}}, \mathrm{cm}\right)$, relative height of maximum leaf area density $\left(1-L D_{a}\right)$, leaf area distribution shape coefficient $\left(L D_{b}\right)$ and extinction coefficients for diffuse radiation $\left(K_{d f}\right)$

\begin{tabular}{|c|c|c|c|c|c|c|c|c|c|}
\hline Year & Site & Eff. & $\ln \left(L A I_{o}\right)$ & RGRL & $\mathrm{H}_{\mathrm{a}} / \mathrm{H}_{\mathrm{b}}$ & $\mathrm{H}_{\mathrm{m}}$ & $1-\mathrm{LD}_{\mathrm{a}}$ & $\mathrm{LD}_{\mathrm{b}}$ & $\mathrm{K}_{\mathrm{df}}$ \\
\hline \multirow[t]{6}{*}{1996} & \multirow[t]{3}{*}{ Havelock } & $\mathrm{H}$ & 0.338 & 0.379 & $<0.001$ & $<0.001$ & - & - & - \\
\hline & & W & 0.199 & 0.104 & $<0.001$ & $<0.001$ & - & - & - \\
\hline & & $\mathrm{H} \times \mathrm{W}$ & 0.350 & 0.038 & $<0.001$ & 0.005 & - & - & - \\
\hline & \multirow[t]{3}{*}{ Mead } & $\mathrm{H}$ & 0.039 & 0.073 & $<0.001$ & $<0.001$ & - & - & - \\
\hline & & w & 0.392 & 0.500 & 0.064 & 0.001 & - & - & - \\
\hline & & $\mathrm{H} \times \mathrm{W}$ & 0.681 & 0.723 & $<0.001$ & $<0.001$ & - & - & - \\
\hline \multirow[t]{6}{*}{1997} & \multirow[t]{3}{*}{ Havelock } & $\mathrm{H}$ & 0.241 & 0.250 & 0.004 & $<0.001$ & 0.035 & 0.644 & $<0.001$ \\
\hline & & W & 0.436 & 0.356 & 0.003 & 0.001 & 0.986 & 0.991 & - \\
\hline & & $\mathrm{H} \times \mathrm{W}$ & 0.167 & 0.215 & $<0.001$ & 0.010 & 0.020 & 0.440 & - \\
\hline & \multirow[t]{3}{*}{ Mead } & $\mathrm{H}$ & 0.001 & 0.031 & $<0.001$ & $<0.001$ & 0.004 & 0.001 & $<0.001$ \\
\hline & & W & 0.879 & 0.994 & 0.007 & 0.007 & 0.172 & 0.972 & - \\
\hline & & $\mathrm{H} \times \mathrm{W}$ & 0.576 & 0.020 & $<0.001$ & $<0.001$ & 0.027 & 0.042 & - \\
\hline
\end{tabular}


Table 3. Mean sorghum apparent leaf area at emergence $\left[\ln \left(\mathrm{LAl}_{\mathrm{o}}\right)\right]$, early leaf area growth rate $\left[R G R L\left(\mathrm{~d}^{\circ} \mathrm{C}\right)^{-1}\right]$, thermal time to $50 \%$ maximum height $\left(\mathrm{H}_{\mathrm{a}} / \mathrm{H}_{\mathrm{b}}, \mathrm{d}^{\circ} \mathrm{C}\right)$ and maximum height $\left(\mathrm{H}_{\mathrm{m}}, \mathrm{cm}\right)$ at Havelock and Mead in 1996

\begin{tabular}{|c|c|c|c|c|c|c|c|c|}
\hline \multirow[b]{2}{*}{ Treatments } & \multicolumn{4}{|c|}{ Havelock } & \multicolumn{4}{|l|}{ Mead } \\
\hline & $\ln \left(\mathrm{LAI}_{\mathrm{o}}\right)$ & RGRL & $\mathrm{H}_{\mathrm{a}} / \mathrm{H}_{\mathrm{b}}$ & $\mathrm{H}_{\mathrm{m}}$ & $\ln \left(\mathrm{LAI}_{\mathrm{o}}\right)$ & RGRL & $\mathrm{H}_{\mathrm{a}} / \mathrm{H}_{\mathrm{b}}$ & $\mathrm{H}_{\mathrm{m}}$ \\
\hline FS2 no weed & -4.89 & 0.018 & 377 & 240 & -5.54 & 0.023 & 380 & 221 \\
\hline FS2 high weed & -4.89 & 0.019 & 356 & 234 & -5.54 & 0.023 & 338 & 198 \\
\hline DK54 no weed & -4.89 & 0.022 & 242 & 145 & -6.02 & 0.025 & 251 & 133 \\
\hline X260 no weed & -4.89 & 0.021 & 242 & 143 & -5.96 & 0.025 & 246 & 128 \\
\hline X260 low weed & -4.89 & 0.021 & 235 & 141 & -5.96 & 0.025 & 244 & 127 \\
\hline X260 high weed & -4.89 & 0.018 & 214 & 118 & -5.96 & 0.025 & 242 & 121 \\
\hline SE & 0.089 & 0.0005 & 6.0 & 3.6 & 0.150 & 0.0007 & 8.4 & 4.9 \\
\hline
\end{tabular}

Abutilon theophrasti has been reported to have a low growth rate early in its development, with greatest growth occurring about 6-8 weeks after emergence (Roeth et al., 1983). Weed $\ln \left(\mathrm{LAI}_{\mathrm{o}}\right)$ and RGRL were always lower than that of sorghum (Table 5, statistics not shown) and similar to those reported by Lindquist \& Mortensen (1999). Weed RGRL was reduced equally by the three sorghum hybrids (Table 5).

Height growth rate and maximum height

A hybrid-infestation level interaction was observed for maximum height in all site-years (Table 2). In monoculture treatments, the tall hybrid (FS2) reached a greater maximum height $\left(\mathrm{H}_{\mathrm{m}}\right)$ than the other hybrids (Tables 3 and 4). Maximum height of all hybrids was reduced by about $10 \%$ in mixture with $A$. theophrasti. Monoculturegrown $A$. theophrasti reached a higher $\mathrm{H}_{\mathrm{m}}$ than in mixture (Table 5). Maximum height of $A$. theophrasti was reduced equally in the presence of all hybrids in all siteyears (Table 5). Height reduction ranged from $22 \%$ to $60 \%$ depending on location and year. The weed grew taller than the two medium hybrids in all site-years ex- cept Mead in 1997, giving A. theophrasti a net competitive advantage in mixture with the short or medium sorghum hybrids in those site-years. Similar height differences have been reported for $A$. theophrasti competing with other crops (Roeth et al., 1983). Akey et al. (1990) attributed greater light interception to a greater $A$. theophrasti height and dry matter allocation to branches in the upper layers of the canopy when competing with Glycine max L.

Differences in height can contribute to differences in competitiveness between hybrids by increasing the ability of the crop to shade weeds. A strong correlation between maximum plant height and competitive ability has been demonstrated for many crop species (Berkowitz, 1988). Our results indicate that, because the tall sorghum hybrid was taller than $A$. theophrasti, it may be more competitive for light than the medium-stature hybrids, which were typically shorter than A. theophrasti late in the season. Variation in time course of height growth among hybrids may also contribute to differences in time to canopy closure, the time course of radiation interception and, ultimately, differences in rela-

Table 4. Mean sorghum apparent leaf area at emergence $\left[\ln \left(\mathrm{LAl} \mathrm{I}_{\mathrm{o}}\right)\right]$, early leaf area growth rate $\left[R G R L\left(\mathrm{~d}^{\circ} \mathrm{C}\right)^{-1}\right]$, thermal time to $50 \%$ maximum height $\left(\mathrm{H}_{\mathrm{a}} / \mathrm{H}_{\mathrm{b}}, \mathrm{d}^{\circ} \mathrm{C}\right)$, maximum height $\left(\mathrm{H}_{\mathrm{m}}, \mathrm{cm}\right)$, relative height of maximum leaf area density $\left(1-\mathrm{LD}_{\mathrm{a}}\right)$ and leaf area distribution shape coefficient $\left(\mathrm{LD}_{\mathrm{b}}\right)$ at Havelock and Mead in 1997

\begin{tabular}{|c|c|c|c|c|c|c|c|c|c|c|c|c|}
\hline \multirow[b]{2}{*}{ Treatments } & \multicolumn{6}{|c|}{ Havelock } & \multicolumn{6}{|l|}{ Mead } \\
\hline & $\ln \left(\mathrm{LAI}_{\mathrm{o}}\right)$ & RGRL & $\mathrm{H}_{\mathrm{a}} / \mathrm{H}_{\mathrm{b}}$ & $\mathrm{H}_{\mathrm{m}}$ & $1-\mathrm{LD}_{\mathrm{a}}$ & $\mathrm{LD}_{\mathrm{b}}$ & $\ln \left(L A I_{o}\right)$ & RGRL & $\mathrm{H}_{\mathrm{a}} / \mathrm{H}_{\mathrm{b}}$ & $\mathrm{H}_{\mathrm{m}}$ & $1-\mathrm{LD}_{\mathrm{a}}$ & $\mathrm{LD}_{\mathrm{b}}$ \\
\hline FS2 no weed & -4.36 & 0.018 & 275 & 176 & 0.637 & 3.05 & -6.60 & 0.028 & 239 & 141 & 0.534 & 3.50 \\
\hline FS2 low weed & -4.36 & 0.018 & 265 & 166 & 0.635 & 3.05 & -6.60 & 0.030 & 242 & 147 & 0.527 & 3.17 \\
\hline FS2 high weed & -4.36 & 0.018 & 256 & 158 & 0.606 & 3.05 & -6.60 & 0.029 & 239 & 146 & 0.572 & 3.22 \\
\hline DK54 no weed & -4.36 & 0.018 & 228 & 126 & 0.626 & 3.05 & -7.51 & 0.032 & 246 & 159 & 0.559 & 3.43 \\
\hline DK54 low weed & -4.36 & 0.018 & 228 & 130 & 0.653 & 3.05 & -7.51 & 0.032 & 243 & 156 & 0.541 & 3.54 \\
\hline DK54 high weed & -4.36 & 0.018 & 220 & 121 & 0.655 & 3.05 & -7.51 & 0.032 & 243 & 156 & 0.556 & 3.43 \\
\hline X260 no weed & -4.36 & 0.018 & 216 & 118 & 0.686 & 3.05 & -6.90 & 0.032 & 240 & 145 & 0.621 & 2.46 \\
\hline X260 low weed & -4.36 & 0.018 & 215 & 118 & 0.667 & 3.05 & -6.90 & 0.029 & 240 & 147 & 0.614 & 2.52 \\
\hline X260 high weed & -4.36 & 0.018 & 211 & 116 & 0.688 & 3.05 & -6.90 & 0.030 & 232 & 141 & 0.612 & 2.66 \\
\hline SE & 0.175 & 0.0009 & 8.8 & 4.7 & 0.0188 & 0.153 & 0.322 & 0.0014 & 7.3 & 2.2 & 0.0104 & 0.159 \\
\hline
\end{tabular}


Table 5. Mean $A$. theophrasti apparent leaf area at emergence $\left[\ln \left(\mathrm{LAI}_{\mathrm{o}}\right)\right]$, leaf area growth rate $\left[R G R L\left(d^{\circ} \mathrm{C}\right)^{-1}\right]$, thermal time to $50 \%$ maximum height $\left(\mathrm{H}_{a} / \mathrm{H}_{b}, d^{\circ} \mathrm{C}\right)$, maximum height $\left(\mathrm{H}_{m}, \mathrm{~cm}\right)$, relative height of maximum leaf area density $\left(1-\mathrm{LD}_{a}\right)$ and the leaf area distribution shape coefficient $\left(\mathrm{LD}_{b}\right)$

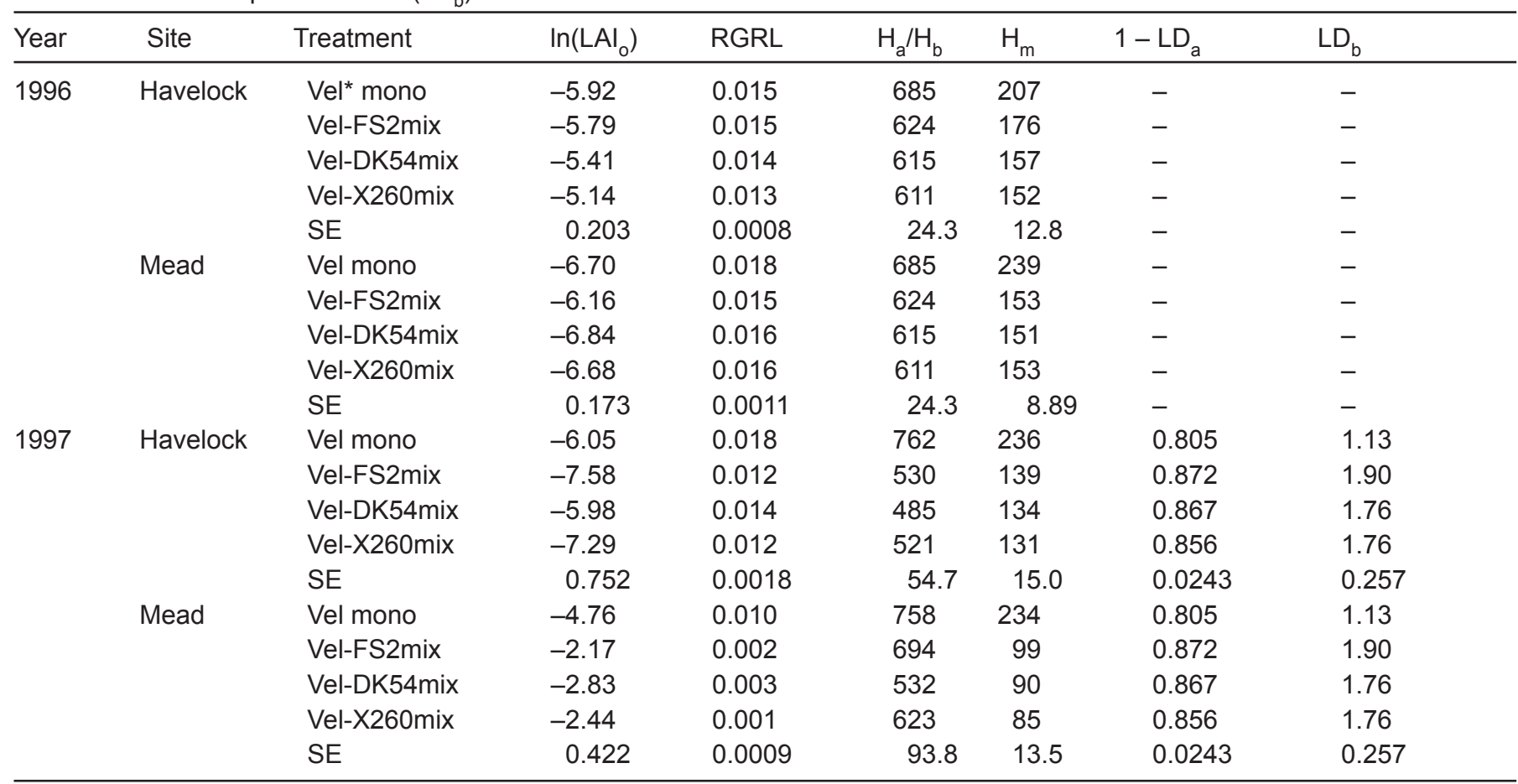

${ }^{*}$ Vel $=$ A. theophrasti in monoculture or mixture.

tive competitive ability (Lindquist et al., 1998). Because height parameters differed among years and locations, our results indicate that height growth and its response to interference is dependent in part upon environmental conditions. Further research directed at understanding crop and weed height growth response to edaphic and micrometeorological conditions is needed.

\section{Leaf area distribution}

Vertical leaf area distribution was measured only in 1997. There was a sorghum hybrid-weed infestation interaction for both leaf area distribution parameters at Havelock and Mead (Table 2). Relative height at which maximum leaf area density occurs $\left(1-\mathrm{LD}_{\mathrm{a}}\right)$ was higher for the medium hybrid X260 than for the other hybrids grown in monoculture at both sites (Table 4). However, actual height at which maximum leaf area density occurs $\left[\mathrm{H}_{\mathrm{m}}\left(1-\mathrm{LD}_{\mathrm{a}}\right)\right]$ was higher for the tall sorghum hybrid than for the two medium hybrids grown in monoculture (Figure 1). The relative height of maximum leaf area density of $A$. theophrasti grown in monoculture was much higher than for all sorghum hybrids (Table 5), suggesting that, if all plants were the same height in mixture, A. theophrasti would have a large proportion of its leaf area above the sorghum canopy. However, because FS2 was taller than A. theophrasti in mixture, whereas A. theophrasti was taller than X260 and DK54, FS2 was not as severely shaded by $A$. theophrasti late in the growing season. Height of maximum leaf area density of FS2 decreased in mixture at Havelock, whereas that of DK54 increased and that of X260 did not vary. In contrast, height of maximum leaf area density of FS2 increased in mixture at Mead, whereas that of DK54 and X260 did not vary from monoculture. The differential response of vertical leaf area distribution of sorghum hybrids to $A$. theophrasti infestation among sites was probably caused by differences in the intensity of competition between sorghum and $A$. theophrasti resulting from different soil moisture conditions. Mediumstature sorghum hybrids were shaded by $A$. theophrasti late in the growing season, suggesting that $A$. theophrasti will intercept a greater proportion of the incident PPFD at the expense of medium sorghum hybrids. Maximum A. theophrasti leaf area density was closer to the top of the $A$. theophrasti plant when grown in mixture, probably because of the senescence of leaves low in the canopy. However, because A. theophrast $\mathrm{H}_{\mathrm{m}}$ was reduced in mixture, leaf area was distributed lower in the canopy when grown in mixture with sorghum hybrids compared with $A$. theophrasti in monoculture (Table 5, Figure $1 \mathrm{E}$ and $F$ ). Both sorghum and $A$. theophrasti varied their vertical leaf area distribution as a result of interspecific competition. Any factor that differentially alters a plant's ability to intercept light in relation to that of neighboring plants should influence its ability to compete for light (Rhodes \& Stern, 1978). 


\section{Specific leaf area}

Mean specific leaf area $\left(\mathrm{m}^{2} \mathrm{~g}^{-1}\right.$, SLA) of both $A$. theophrasti and sorghum was similar to values reported by others (McCree, 1983; Bazzaz et al., 1989; Lindquist \& Mortensen, 1999). Sorghum SLA differed among hybrids in monoculture (Figure 2). Early in the season (developmental stage, DVS=0.2), the medium hybrids had greater SLA than the tall sorghum hybrid. Between the medium sorghum hybrids, DK54 had a greater SLA than X260. At early boot stage (DVS=0.6), the tall sorghum hybrid and DK54 had greater SLA than X260. McCree (1983) showed that sorghum SLA decreased with increasing plant size under both controlled environment and field conditions. In mixture with $A$. theophrasti, sorghum SLA showed a similar trend to that observed in monoculture (Figure 2). However, the tall sorghum hybrid and DK54 had greater SLA than X260 early in the season, whereas DK54 had a greater SLA than the other sorghum hybrids late in the season. Abutilon theophrasti in monoculture had lower SLA than sorghum during early development, whereas $A$. theophrasti in mixture

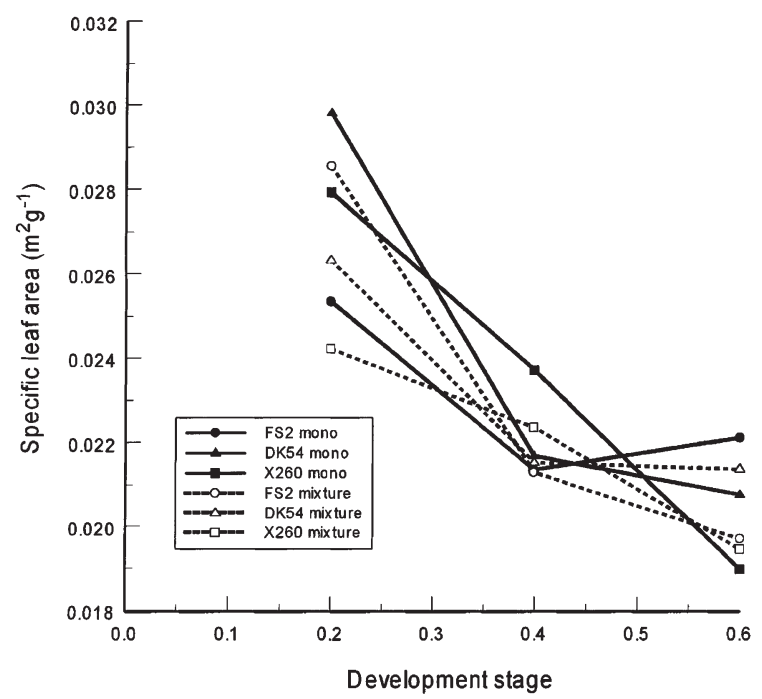

Figure 2. Mean specific leaf area $\left(\mathrm{m}^{2} \mathrm{~g}^{-1}\right)$ as a function of development stage for three sorghum hybrids (FS2, DK54 and $\mathrm{X} 260$ ) grown in monoculture and in mixture with $A$. theophrasti at Havelock in 1996.
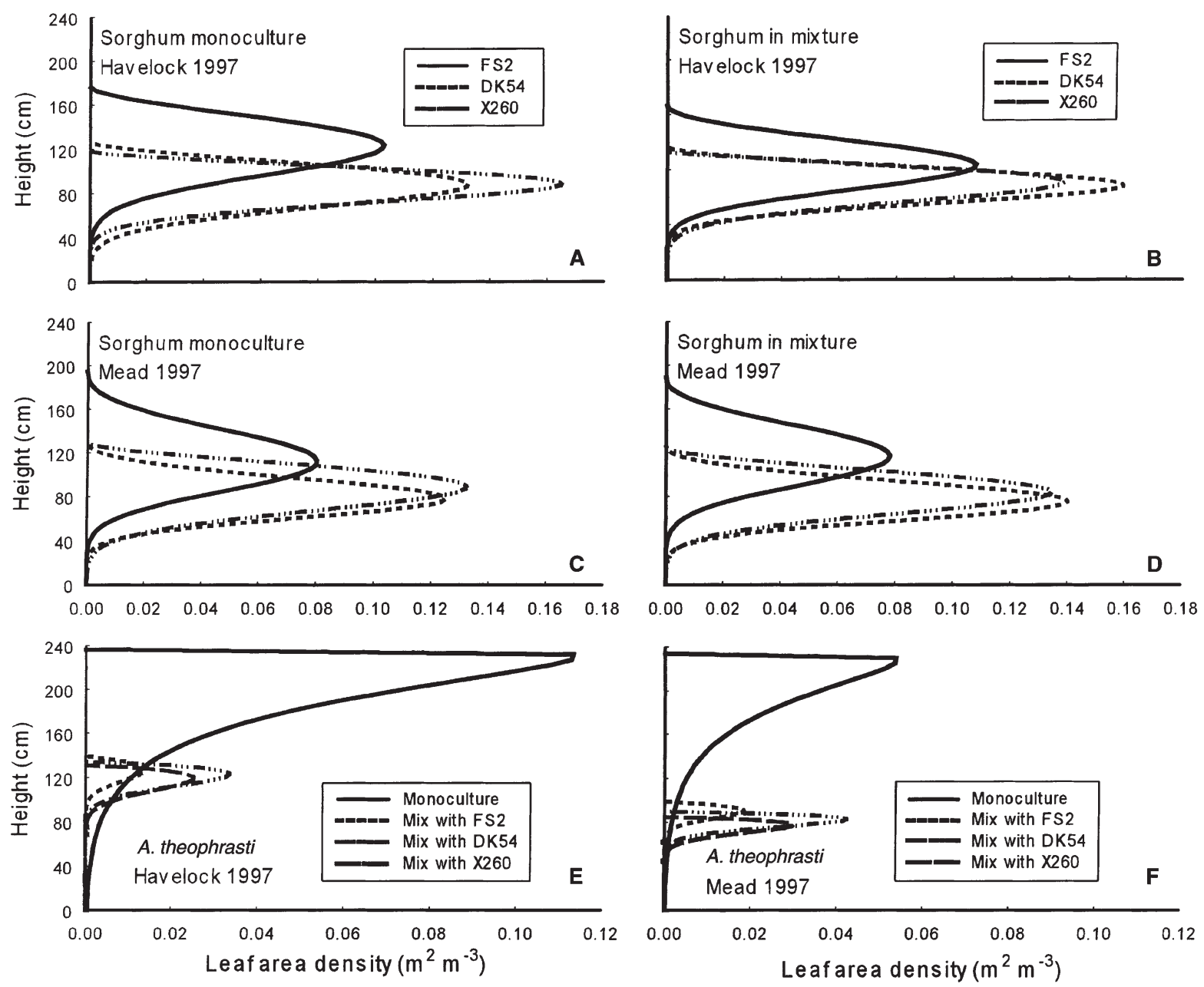

Figure 1. Leaf area density $\left(\mathrm{m}^{2} \mathrm{~m}^{-3}\right)$ over height of sorghum (A-D) and A. theophrasti (E and F) in monoculture and in mixture at Havelock and Mead in 1997. 
had higher SLA than in monoculture (data not shown). Assuming equivalent partitioning of biomass to leaf, a hybrid with a greater SLA will produce the larger LAI (Lindquist \& Mortensen, 1999).

\section{Biomass partitioning}

Partitioning of new biomass to leaf and stem was similar among sorghum hybrids grown in monoculture and in mixture except at Havelock in 1996, where a hybrid $\times$ weed infestation $\times$ sample date interaction was observed for the leaf partitioning coefficients (Table 6). This interaction indicates that the response of sorghum hybrids to $A$. theophrasti interference varied with development stage (DVS) of the crop. In monoculture, the partitioning of new biomass to leaf and stem was similar among sorghum hybrids and decreased with development stage (Figures $3 \mathrm{~A}$ and $\mathrm{C}$ ). In mixtures, partitioning of new biomass to leaf and stem was similar among sorghum hybrids during the early stages of development. However, the tall hybrid partitioned less new biomass to leaf and more biomass to stem compared with the medium hybrids at DVS=0.6 (Figure 3B). The increase in biomass partitioned to stem contributed to the lack of height response of FS2 to A. theophrasti competition in that site-year. Partitioning of new biomass to panicle was similar among hybrids at Mead, whereas the medium sorghum hybrids partitioned more new biomass to panicle than the tall hybrid at Havelock. The partitioning of new biomass to leaf and stem in A. theophrasti was similar in mixture with the three hybrids (Table 7). Weed stem and reproductive organs were combined late in the season, and no partitioning coefficient was assessed for reproductive organs (data not shown).

\section{Radiation attenuation into the canopy}

Estimates of extinction coefficients for diffuse radiation differed among sorghum hybrids in monoculture (Table 2). Extinction coefficients were greater $\left(\mathrm{K}_{\mathrm{df}}=\right.$ $0.62 \pm 0.034)$ for medium sorghum hybrids than for the tall hybrid $\left(\mathrm{K}_{\mathrm{df}}=0.54 \pm 0.034\right)$. The extinction coefficient for monoculture-grown $A$. theophrasti was smaller $\left(\mathrm{K}_{\mathrm{df}}=0.45 \pm 0.034\right)$ than that of sorghum. The smaller value of $\mathrm{K}_{\mathrm{df}}$ for $A$. theophrasti is contrary to theoretical predictions, as $A$. theophrasti leaf angle distribution appears more planophile than that of sorghum. However, Lindquist \& Mortensen (1999) also showed that A. theophrasti $\mathrm{K}_{\mathrm{df}}$ was smaller than that of maize. The smaller $\mathrm{K}_{\mathrm{df}}$ may be the result of greater transmission of PPFD through leaves. Estimates of $\mathrm{K}_{\mathrm{df}}$ for sorghum and A. theophrasti were within the range of those reported by others (Flenet et al., 1996; Lindquist \& Mortensen, 1999). Greater extinction coefficients indicate that more radiation is intercepted per unit leaf area and may confer greater competitive advantage to the hybrid by providing more shade.

\section{Conclusions}

Tolerance to and suppression of $A$. theophrasti growth differed among sorghum hybrids. In general, the tall hybrid FS2 was more tolerant to $A$. theophrasti interference at all site-years. The tall hybrid also suppressed $A$. theophrasti growth more than the other hybrids, but only in one site-year. Ecophysiological characteristics and their response to $A$. theophrasti competition varied among sorghum hybrids, indicating that certain canopy characteristics may contribute to differences in hybrid toler-

Table 6. Analysis of variance showing probabilities (P-values) of the main effects of sorghum hybrid $(\mathrm{H})$, weed infestation $(\mathrm{W})$ and interactions on sorghum mean estimated partitioning coefficients for leaf and stem at Havelock and Mead in 1996 and 1997.

\begin{tabular}{|c|c|c|c|c|}
\hline \multirow[b]{2}{*}{ Year/treatment } & \multicolumn{2}{|c|}{ Havelock } & \multicolumn{2}{|l|}{ Mead } \\
\hline & Pcleaf & Pcstem & Pcleaf & Pcstem \\
\hline \multicolumn{5}{|l|}{1996} \\
\hline $\mathrm{H}$ & 0.881 & 0.046 & 0.868 & 0.798 \\
\hline W & 0.860 & 0.105 & 0.271 & 0.869 \\
\hline $\mathrm{H} \times \mathrm{W}$ & 0.412 & 0.430 & 0.957 & 0.122 \\
\hline Sample time (samp) & $<0.001$ & $<0.001$ & $<0.001$ & $<0.001$ \\
\hline $\mathrm{H} \times$ samp & 0.123 & 0.047 & 0.839 & 0.553 \\
\hline W×samp & 0.821 & 0.873 & 0.037 & 0.047 \\
\hline $\mathrm{H} \times \mathrm{W} \times$ samp & 0.014 & 0.442 & 0.749 & 0.934 \\
\hline \multicolumn{5}{|l|}{1997} \\
\hline $\mathrm{H}$ & 0.151 & 0.081 & 0.067 & 0.037 \\
\hline W & 0.157 & 0.400 & 0.631 & 0.118 \\
\hline $\mathrm{H} \times \mathrm{W}$ & 0.415 & 0.531 & 0.729 & 0.273 \\
\hline Sample time (samp) & $<0.001$ & $<0.001$ & $<0.001$ & $<0.001$ \\
\hline $\mathrm{H} \times$ samp & 0.165 & 0.253 & 0.128 & 0.362 \\
\hline $\mathrm{W} \times$ samp & 0.215 & 0.228 & 0.192 & 0.037 \\
\hline $\mathrm{H} \times \mathrm{W} \times$ samp & 0.616 & 0.280 & 0.358 & 0.406 \\
\hline
\end{tabular}




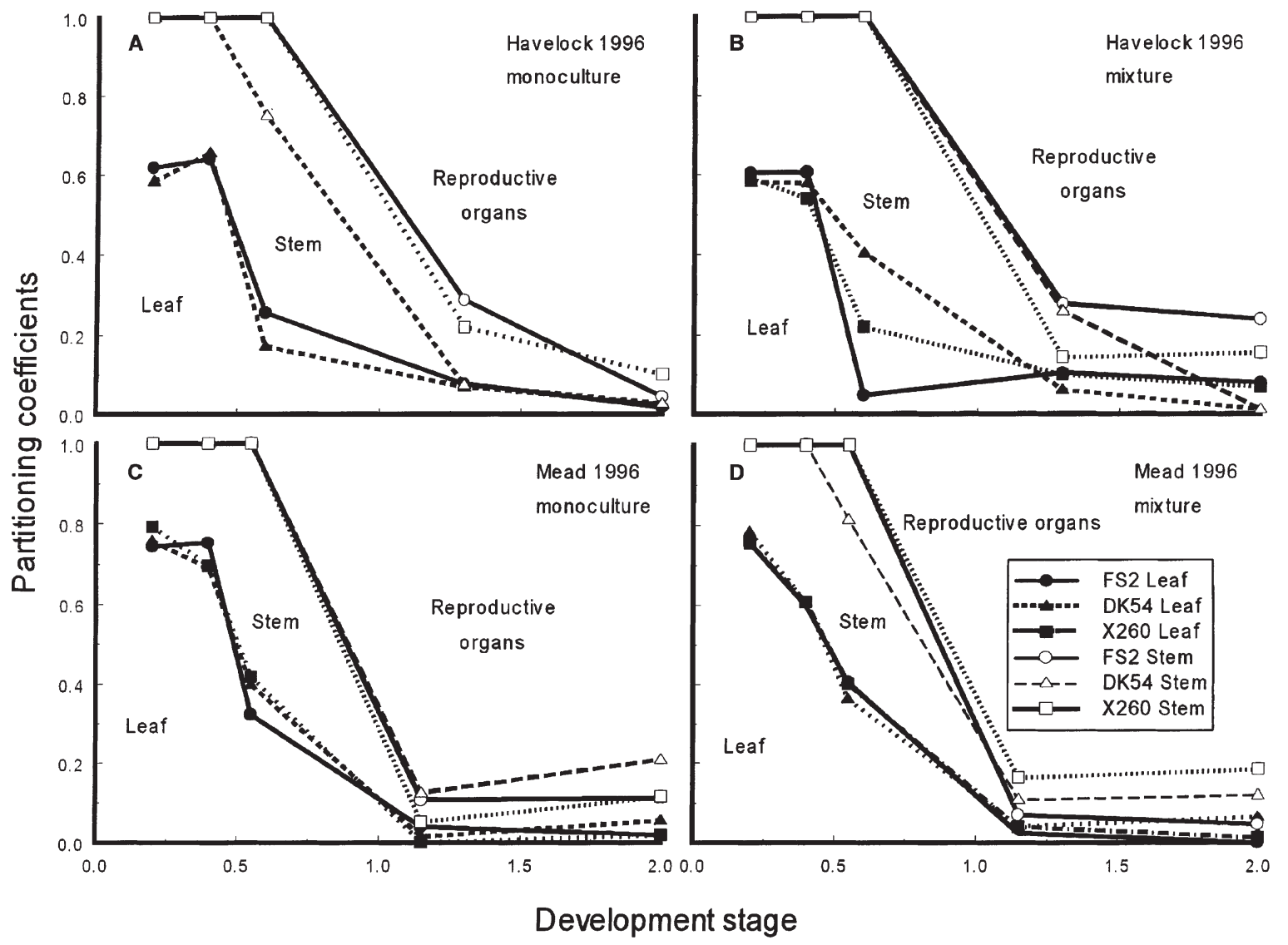

Figure 3. Partitioning of new biomass to leaf, stem and reproductive organs of three sorghum hybrids grown in monoculture (A and C) and in mixture (B and D) at Havelock and Mead in 1996.

ance and $A$. theophrasti suppression. Sorghum hybrids suppressed $A$. theophrasti early season leaf area growth equally. Maximum height was greater for the tall sorghum hybrid than for the medium hybrids in monoculture. Although thermal time to $50 \%$ maximum height was also greater, FS2 height exceeded that of the medium-stature hybrids at an early growth stage. Greater height early in the season can contribute to differences in tolerance and suppressive ability among hybrids. The tall hybrid had its leaf area distributed higher in the canopy than the medium hybrids, which may contribute to greater light interception by the tall hybrid late in the season compared with medium hybrids, especially in mixture. Monoculture A. theophrasti leaf area was distributed higher in the canopy than that of sorghum, but both height and vertical leaf area distribution were strongly reduced in mixture. Despite a substantial reduction in height, $A$. theophrasti was able to overtop medium-stature hybrids. The greater height combined with greater leaf area density high in the A. theophrasti

Table 7. Analysis of variance showing probabilities (P-values) for the main effects of sorghum hybrid $(\mathrm{H})$, sample time and interactions on $A$. theophrasti mean estimated partitioning coefficients for leaf and stem at Havelock and Mead in 1996 and 1997.

\begin{tabular}{lrrrrr}
\hline & \multicolumn{2}{l}{ Havelock } & & \multicolumn{2}{l}{ Mead } \\
\cline { 2 - 3 } & Pcleaf & Pcstem & & Pcleaf & Pcstem \\
\hline 1996 & & & & \\
H & 0.136 & 0.136 & & 0.856 & 0.856 \\
Sample time & $<0.001$ & $<0.001$ & & $<0.001$ & $<0.001$ \\
H×sample time & 0.060 & 0.060 & & 0.157 & 0.157 \\
1997 & & & & \\
H & 0.252 & 0.252 & & 0.067 & 0.067 \\
Sample time & 0.003 & 0.003 & $<0.001$ & $<0.001$ \\
H×sample time & 0.264 & 0.264 & 0.128 & 0.128 \\
\hline
\end{tabular}


canopy contributed to greater light interception by the weed at the expense of the medium-stature hybrids. The ability to modify the height of maximum leaf area density in the presence of $A$. theophrasti may be an important mechanism for improved tolerance and weed suppression. Greater extinction coefficients for diffuse radiation for the medium hybrids indicate greater efficiency of radiation interception per unit leaf area. In a sensitivity analysis of the model INTERCOM, Lindquist \& Mortensen (1997) showed that an increase in $K_{d f}$ may improve crop tolerance to weed interference, but yield in monoculture was reduced because of the reduced penetration of high-intensity radiation to lower canopy layers. Therefore, the lower $\mathrm{K}_{\mathrm{df}}$ for the tall sorghum hybrid may reduce its competitive ability, but increase its weed-free crop yield. Specific leaf area of sorghum hybrids is generally reduced in mixture with $A$. theophrast $i$ during early season growth. However, SLA of the medium hybrids increased in mixture later in the season, whereas the tall sorghum SLA was reduced in mixture. Specific leaf area reflects leaf thickness and the relative proportion of assimilatory and conductive or mechanical tissues in leaves (Kvet et al., 1971). The increase in SLA of the medium hybrids in mixture may have been the result of acclimation to optimize $\mathrm{CO}_{2}$ assimilation in a light-limiting environment (below the $A$. theophrasti canopy). Because leaves of the tall sorghum hybrid were above that of $A$. theophrasti (and therefore not light limited), acclimation to reduced radiation was not necessary for FS2. Greater partitioning of new biomass to leaf during vegetative development may reduce the time to canopy closure and lead to greater tolerance and weed suppressive ability. Selection of hybrids with greater competitiveness with weeds through improved light utilization remains one approach to improving crop productivity in the presence of weeds. The results of this study indicate that careful selection of sorghum hybrid may improve sorghum productivity in the presence of A. theophrasti.

Acknowledgments - A contribution of the University of Nebraska Agricultural Research Division Journal Series no. 13044.

\section{References}

AKEY WC, JURIK TW \& DEKKER J (1990) Competition for light between velvetleaf (Abutilon theophrasti) and soybean (Glycine max). Weed Research 30 , 403-411.

BAZZAZ FA, GARBUTT K, REEKIE EG \& WILLIAMS WE (1989) Using growth analysis to interpret competition between a $\mathrm{C}_{3}$ and $\mathrm{C}_{4}$ annual under ambient and elevated $\mathrm{CO}_{2}$. Oecologia $79,223-235$.
BERKOWITZ AR (1988) Competition for resources in weedcrop mixtures. In: Weed Management in Agroecosystems: Ecological Approaches (eds. M ALTIERI \& M LIEBMAN), 89119. CRC Press, Boca Raton, FL, USA.

CHANDLER JM (1981) Estimating losses of crops to weeds. In: Handbook of Pest Management in Agriculture (ed. D PIMENTAL), Vol. I, 95-109. CRC Press, Boca Raton, FL, USA.

EASTIN JD (1972) Efficiency of grain dry matter accumulation in sorghum. In: Proceedings 27th Annual Maize and Sorghum Research Conference, Chicago, IL, USA, (eds. JL SUTHERLAND \& RJ FALASCA), 7-17. American Seed Trade Association.

FLENET R, KINIRY JR, BOARD JE, WESTGATE ME \& REICOSKY DC (1996) Row spacing effects on light extinction coefficients of maize, sorghum, soybean, and sunflower. Agronomy Journal 88 , 185-190.

ICRISAT (INTERNATIONAL CROPS RESEARCH INSTITUTE FOR THE SEMI-ARID TROPICS) (1990) ICRISAT Crops and their Environment. Annual Report 1989. ICRISAT, Patencheru, India.

JORDAN N (1993) Prospects for weed control through crop interference. Ecological Applications 3, 84-91.

KHEDIR DK \& ROETH FW (1981) Velvetleaf (Abutilon theophrasti) seed populations in six continuous corn (Zea mays) fields. Weed seed dormancy. Weed Science 29, 485-490.

KVET J, ONDOCK JP, NECAS J \& JARVIS PG (1971) Methods of growth analysis. In: Plant Photosynthetic Production; Manual of Methods (eds. Z SESTAK, J CSTSKY \& PG JARVIS), 353-392. Dr W Junk NV Publishers, The Hague, The Netherlands.

LAGOKE STO, PARKINSON V \& AGUNBIADE RM (1991) Parasitic weeds and control methods in Africa. In: Combating Striga in Africa. Proceedings of an International Workshop, 22-24 August 1988. Ibadan, Nigeria, 3-14.

LAWLOR DW (1995) Photosynthesis, productivity and environment. Journal of Experimental Botany 46 (special issue),1449-1461.

LINDQUIST JL \& MORTENSEN DA (1997) A simulation approach to identifying the mechanisms of maize tolerance to velvetleaf competition for light. In: Proceedings 1997 Brighton Crop Protection Conference- Weeds, Brighton, UK, 503-508.

LINDQUIST JL \& MORTENSEN DA (1998) Tolerance and velvetleaf (Abutilon theophrasti) suppressive ability of two old and two modern corn (Zea mays) hybrids. Weed Science 46, 569-574.

LINDQUIST JL \& MORTENSEN DA (1999) Ecophysiological characteristics of four maize hybrids and Abutilon theophrasti. Weed Research 39, 271-285.

LINDQUIST JL, MORTENSEN DA \& JOHNSON BE (1998) Mechanism of corn tolerance and velvetleaf suppressive ability. Agronomy Journal 90, 787-792.

MCCREE K (1983) Carbon balance as a function of plant size in sorghum plants. Crop Science 23, 1173-1177.

MUNGER PH, CHANDLER JM, COTHREN JT \& HONS FM (1987) Soybean (Glycine max)-velvetleaf (Abutilon theophrasti) interspecific competition. Weed Science 35, 647-653. 
RHODES I \& STERN WR (1978) Competition for light. In: Plant Relations in Pastures (ed. JR WILSON), 175-189. CSIRO, Canberra, Australia.

ROETH F, MOOMAW R, MARTIN A \& BURNSIDE O (1983) Velvetleaf, NebGuide G83-681. Cooperative Extension Service, Institute of Agriculture and Natural Resources, University of Nebraska- Lincoln, Lincoln, NE, USA.

SAS (1996) System for Mixed Models. SAS Institute Incorporation, Cary, NC, USA.
SPENCER NR (1984) Velvetleaf, Abutilon theophrasti (Malvaceae), history and economic impact in the United States. Economic Botany 38, 407-416.

SPITTERS CJT (1986) Separating the diffuse and direct component of global radiation and its implications for modeling canopy photosynthesis. Part II. Calculation of canopy photosynthesis. Agricultural and Forest Meteorology 38, 231-242.

TRAORÉ S (1999) Effects of Genotypes and Weed Removal on the Competitive Ability of Grain Sorghum. PhD Thesis, University of Nebraska, Lincoln, NE, USA. 